\title{
FOREST FIRE RISK FORECAST FOR THE STATE OF SANTA CATARINA DUE TO CLIMATE CHANGES
}

\author{
Tatiane Lima Ho ${ }^{1 *}$, Antonio Carlos Batista ${ }^{2}$, Alexandre França Tetto ${ }^{2}$ \\ 1* Federal University of Paraná, Graduate Program of Forestry, Curitiba, Paraná, Brazil - tatiane.1.ho@ gmail.com \\ 2 Federal University of Paraná, Department of Forestry Science, Curitiba, Paraná, Brazil - batistaufpr@ufpr.br, tetto@ufpr.br
}

Received for publication: 23/02/2017 - Accepted for publication: 22/08/2017

\begin{abstract}
Forest plays a fundamental role in the environmental balance, mainly in the regulation of the climate, main variable that interferes in the propagation of fire in a forest fire. Climate change is caused by astronomic, natural and anthropogenic factors, the latter being primarily responsible for the change in the fire regime. There is a projection that there will be climate changes over the next 100 years, which will result in an impact on forest ecosystems. Therefore, this study aimed to was to determine, by decade, the Forest Fire Risk Zone Mapping (FFRZM) for the state of Santa Catarina by considering the average of two scenarios for the increase of the temperature of the Earth until $2100\left(1{ }^{\circ} \mathrm{C}\right.$ for the best-case scenario and $2.2{ }^{\circ} \mathrm{C}$ for the worstcase scenario) that were foreseen by the Intergovernmental Panel on Climate Change (IPCC) in 2013. For this purpose, eight variables classified according to fire risk and integrated in a weighting model were used. The results showed that, for both scenarios, there will be an increase of $11.48 \%$ in the best-case scenario and $10.83 \%$ in the worst-case scenario in the extreme risk class from 2010 to 2100 . For the low risk one, we estimate that there will be an increase of $8.13 \%$ in the best-case scenario and $11.62 \%$ in the worst-case scenario. The study reveals that if there is an increase in the temperature of the Earth, there may be an increase in the number of forest fire occurrences in the state of Santa Catarina for both scenarios. Thus, it is necessary a greater action on the prevention and combat in the areas defined as extreme risk.

Keywords: Fuel load; Monte Alegre Formula; topography; population density; road system.
\end{abstract}

\section{Resumo}

Previsão do risco de incêndios florestais para o estado de Santa Catarina em função das mudanças climáticas A floresta desenvolve um papel fundamental no equilíbrio ambiental, principalmente, na regulação do clima, variável principal que interfere na propagação do fogo em um incêndio florestal. As mudanças climáticas são causadas por fatores astronômicos, naturais e antropogênicos, sendo este último o principal responsável pela mudança no regime do fogo. Há uma projeção de que haverá alterações climáticas nos próximos 100 anos, o que ocasionará um impacto nos ecossistemas florestais. O objetivo desse trabalho foi determinar, por decênio, o Zoneamento de Risco de Incêndios Florestais (ZRIF) para o estado de Santa Catarina, considerando a média de dois cenários de aumento da temperatura da Terra até $2100\left(1{ }^{\circ} \mathrm{C}\right.$ para o melhor cenário e $2,2{ }^{\circ} \mathrm{C}$ para o pior cenário) previstos pelo Painel Intergovernamental de Mudanças Climáticas (IPCC) em 2013. Para isso, foram utilizadas oito variáveis, que foram classificadas em função do risco de incêndios e integradas em um modelo de ponderação. Os resultados mostraram que, para ambos os cenários, haverá um aumento na classe de risco extremo de $11,48 \%$ no melhor cenário e de $10,83 \%$ no pior cenário no período de 2010 a 2100 . Para o risco baixo, estima-se que haverá um aumento de $8,13 \%$ no melhor cenário e de $11,62 \%$ no pior cenário. Conclui-se que, caso haja aumento na temperatura da Terra, poderá haver um aumento no número de ocorrências de incêndios florestais no estado de Santa Catarina para ambos os cenários, Sendo necessária uma maior ação de prevenção e combate nas áreas definidas como risco extremo.

Palavras-chave: Material combustível; Fórmula de Monte Alegre; topografia; densidade demográfica; sistema viário.

\section{INTRODUCTION}

Forests perform important ecological functions in balancing the environment and play a significant role in climate regulation. Forest fires are one of the factors that affect forest conservation and can be intensified by changes in the climate, and cause environmental, economic and social damages (POURTAGHI; POURGHASEMI; ROSSI, 2015). Some ecosystems, such as the Brazilian Cerrado and the African Savanna, are resistant and dependent on fire, but its high occurrence may also generate losses (BRANDÃO; MIRANDA, 2012). 
Forest fires may occur in greater number in the coming decades due to climate changes, to the interaction between climate, fire and vegetation, and to human activities, thus changing the fire regime (HIGUERA et al., 2009). In addition to climate, factors such as fuel load and terrain topography may result in the increase of forest fires (GANTEAUME et al., 2012).

The influence of vegetation on the relationship between fire and climate is due to the quantity, flammability and moisture of the fuel load (HIGUERA et al., 2009). However, the climate related to the topographic features can influence the fire behavior; and it is different in low and high altitudes (KEANE et al., 2010). These factors may have higher risks in face of the vulnerability of human actions, as in the case of Southern Europe, where $90 \%$ of forest fires were caused by humans, often due to changes in the use of land and to negligence, for example, in places of recreational use of forests (HOYO; ISABEL; VEGA, 2011).

There are studies that use fire danger index to predict the damage potential of a given area based on meteorological conditions (NUNES et al., 2010). However, only this index is not enough, and it is recommended to group several pieces of information that influence the behavior and propagation of fire.

For better control of forest fires, several countries, such as Brazil, are using remote sensing techniques and geographic information systems to monitor and report the occurrence of forest fire at a given location. For Machado, Silva and Biudes (2014), it is possible to obtain reliable and accurate data to elaborate forest fire risk maps and predict fires on large scale according to these techniques. The fire risk mapping allows a more accurate assessment of the problems and enables the obtainment of an occurrence of forest fires forecast, as well as the performance of monitoring and planning with greater security (POURTAGHI; POURGHASEMI; ROSSI, 2015).

Considering the importance of meteorological variables for fuel load moisture content and danger indices, topography, type of vegetation, population density and road network to form the Forest Fire Risk Zone Mapping and the hypothesis of increase in the forest fires occurrence due to the increase of the average temperature of the Earth during this century, the objective of this work was to determine, by decade, the forest fire risk zone mapping for the state of Santa Catarina, considering the scenarios foreseen by the Intergovernmental Panel on Climate Change (IPCC) in 2013.

\section{MATERIAL AND METHODS}

\section{Study area}

The state of Santa Catarina is situated between the parallels $25^{\circ} 57^{\prime} 21^{\prime \prime}$ north latitude and $29^{\circ} 21^{\prime} 17^{\prime}$ ' south latitude and at the meridians $48^{\circ} 19^{\prime} 38^{\prime \prime}$ and $53^{\circ} 50^{\prime} 13^{\prime \prime}$ west of Greenwich. The territory of Santa Catarina covers an area of $95,734 \mathrm{~km} 2$, which corresponds to $1.12 \%$ of the Brazilian area and $16.60 \%$ of the Southern region area. Currently, the state has 295 municipalities and, in relation to the last population census, the resident population in the state is 6,248,436 inhabitants, from which 5,247,913 reside in the urban area and $1,000,523$ in the rural area, with average population density of 65.27 inhab. $/ \mathrm{km} 2$. In the state, altitudes vary from sea level and reach 1,827.0 $\mathrm{m}$ in the Morro da Boa Vista, located in the Serra da Anta Gorda. The climate, according to Köppen classification, is humid mesothermal Cf, including two subtypes, Cfa and Cfb (Brazilian Institute of Geography and Statistics (IBGE), 2010 and 2014).

\section{Methodological procedures for the preparation of risk maps}

The methodology of this research consisted of a careful analysis of two groups of factors, ignition sources and favorable propagation conditions, which enabled the establishment of the potential fire risk of a given region or wherever and how the fire will propagate. Thus, preliminary risk maps were elaborated for eight variables (Table 1), from which five were considered static and three dynamic for the analyzed period (2010 - 2100).

Table 1. Variables used in the forest fire risk zone mapping.

Tabela 1. Variáveis utilizadas no zoneamento de risco de incêndios florestais.

\begin{tabular}{ll}
\hline Static & Dynamic \\
\hline Vegetation cover & Fuel load moisture content \\
Land slope & Fire danger index (FMA) \\
Hypsometry & Population density \\
Hillside orientation & \\
Road system & \\
\hline
\end{tabular}


The fire risk analysis was represented by thematic maps made in GIS environment through the ARCGIS software with spatial resolution of $30 \mathrm{~m}$. The preliminary risk maps were obtained from the attribution of a risk coefficient that ranged from 0 to 5 for each unit of analysis, in which 0 was assigned for no risk and 5 for extreme risk. For the risk characterization, a specific table was used for each variable under analysis.

The variable of vegetation cover (fuel load) represents the vulnerability to fire according to the activity that occurs in each region of the state. The risk map was elaborated based on the vegetation map produced by the Company of Agricultural Research and Technological Diffusion of Santa Catarina (EPAGRI) and IBGE (2004) and was classified according to table 2 .

Table 2. Classification of the risk for vegetation cover.

Tabela 2. Classificação do risco para a cobertura vegetal.

\begin{tabular}{lll}
\hline Soil cover & Risk & Coefficients \\
\hline Agriculture & Moderate & 2 \\
Mining area & Low & 1 \\
Urbanized and/or built area & Very High & 4 \\
Water bodies & Null & 0 \\
Forest cultivation & Extreme & 5 \\
Forest in intermediate or advanced and/or primary stage & Very High & 4 \\
Forest in intermediate stage or advanced and/or primary & High & 3 \\
Mangrove (exclusive pioneer formation) & Moderate & 2 \\
Pasture and natural field & Extreme & 5 \\
Exposed soil & Low & 1 \\
Floodplain and resting vegetation & Moderate & 2 \\
\hline
\end{tabular}

The fuel load moisture content and the fire danger index (FMA), as well as the slopes and altitude orientation, indicate the flammability and combustibility conditions of forest fuel indirectly, which influence the rate of fire propagation.

The meteorological variables (temperature, relative humidity of the air and precipitation) for the determination of the fuel load moisture content and the FMA were obtained in the meteorological stations of EPAGRI. To execute the projection of these variables, a historical series was collected from each meteorological station from 1985 to 2009 , and oscillations in the period were analyzed, in addition to the scenarios RCP2.6 and RCP6.0, which were published in the report of the Intergovernmental Panel on Climate Change (IPCC - 2013). These procedures were taken in order to conduct daily stochastic simulations of these variables for the period from 2010 to 2100, using the program PGECLIMA_R of Ponta Grossa State University (UEPG) (VIRGENS FILHO et al., 2009). The IPCC presents an increase of 0.3 to $1.7^{\circ} \mathrm{C}$ (average $1.0^{\circ} \mathrm{C}$ ) in the average temperature of the Earth up to 2100 as the best-case scenario and an increase of 1.4 to $3.1^{\circ} \mathrm{C}$ (average $2.2{ }^{\circ} \mathrm{C}$ ) in the average temperature of the Earth up to 2100 as the worst-case scenario. (1968):

The calculation of the fuel load moisture content was generated by the equation proposed by Simard

In which: $\mathrm{E}=$ fuel load moisture content, in percentage;

$$
\mathrm{E}=21,06-0,4944 \times \mathrm{H}+0,005565 \times \mathrm{H}^{2}-0,00063 \times \mathrm{H} \times \mathrm{T}(\mathrm{H}>50)
$$

$\mathrm{H}=$ relative humidity of the air (daily average), in percentage;

$\mathrm{T}=$ air temperature (daily average), in ${ }^{\circ} \mathrm{C}$.

This variable was considered dynamic for the analyzed period; thus, two scenarios were generated (best and worst), which resulted in maps for each decade. The results were interpolated using the method "topo to raster" and were classified into 5 risk classes, in which 1 was the class of highest moisture content and 5 the lowest.

For the determination of the fire cumulative index, the relative humidity of the air (directly) and the precipitation (indirectly) were used. The index was calculated for the period from 2010 to 2100 for the best and the worst-case scenarios by means of the Monte Alegre Formula (FMA). The days with the highest probability of fire danger were added interpolated by the method "topo to raster" and classified into five risk classes.

In the variable of hypsometry (altimetry), the coefficients are inversely proportional to the altitude; thus, in its classification, we considered that the higher the altitude the lower the possibility of fire occurrence and propagation. The hillside orientation was classified considering the cardinal and intermediate directions, according to the amount of radiation received. The variable of land slope is associated with the speed and direction of the fire propagation and was classified according to the inclination of the terrain. Data for the 
preparation of the preliminary maps of these variables were used from primary data of the TOPODATA project (National Institute for Space Research - INPE, 2008); for their classification, tables prepared by Eugene et al. (2016) were used.

In order to spatialize the dynamic variable of population density, we used data from IBGE (2010) for the censuses of 1991, 2000 and 2010. Initially, it was necessary to estimate the population for each decade for the subsequent density calculation. For that, the Von Sperling method (2005), which determines a population projection denominated decreasing rate of growth, was used. This method defines that its rate of growth grows up to a certain extent and, as the city grows, the rate declines, i.e., the population tends asymptotically to a saturation value and stagnates later. Thus, the projection of the population of the state in the period from 2020 to 2100 was estimated and separated by decades. The values observed for the population density per municipality were divided into five risk classes according to the classification proposed by Guillermo Julio (1992).

The road system was calculated based on the transport data of the Ministry of Environment (MMA, 2008). Considering that the distance from the road system is inversely proportional to the risk of forest fire, influence buffers were delineated from the axes of the municipal, state, federal and railway lines. The degree of fire risk for this variable was established according to the size of the buffers, as proposed by Salas and Chuvieco (1994).

The preliminary maps were integrated with the aid of a weighting model, which indicated the importance of each variable for the occurrence and propagation of fires in Santa Catarina. This weighting was conceived from an adaptation of the model used for the fire risk zone mapping for the state of Paraná (BATISTA et al., 2014), and resulted in the following formula:

$$
R I F=0,33 \times \frac{(V E G+U M C)}{2}+0,33 \times \frac{(F M A+D E+\text { Hipso }+ \text { Orient })}{4}+0,33 \times \frac{(D D+S V)}{2}
$$

In which: RIF is the forest fire risk calculated in each unit of analysis, VEG is the type of vegetation cover, UMC is the fuel load moisture content, FMA is the fire danger index, DE is the land slope, Hipso is the hypsometry, Orient is the hillside orientation, DD is the population density and SV is the distribution of the road system.

\section{RESULTS}

The preliminary maps of the static variables are presented in Figure 1. The vegetation cover presented the largest part of its area in the high risk class, totaling 3.939.303,78 ha $(41.33 \%$ of the state area). It was followed by the extreme risk, which amounted to $3.654 .556,61$ ha $(38.34 \%)$. Of this total, $68.46 \%$ was concentrated in the serrana, west of Santa Catarina. Regarding the orientation of the slopes, the most representative fire risk class was the low one, with $39.14 \%$ of the total. In the variable declivity, low risk and moderate risk were the most representative classes, with $49.30 \%$ and $21.17 \%$ of the state area respectively. Extreme risk is more frequently found in the west region and corresponds to $6.72 \%$ of the total. Regarding hypsometry, we observed that the high, very high and extreme risk classes accounted for $94.59 \%$ of the state area. The influence of the road system corresponded to 228,346.36 ha, 2.39\% of the total area, which is mainly characterized by the very high risk, with $116.224,9$ ha. 

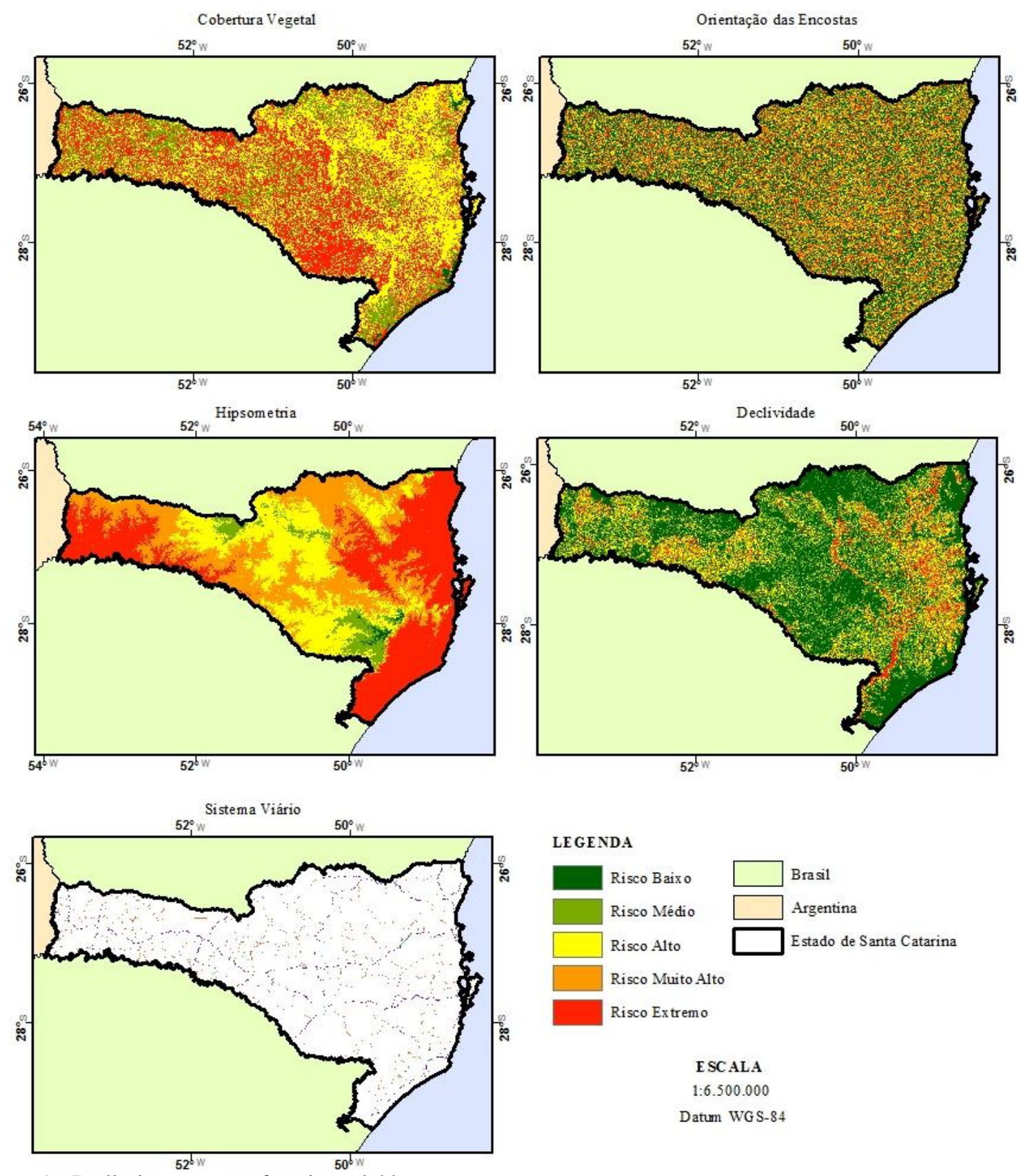

Figure 1. Preliminary maps of static variables.

Figura 1. Mapas preliminares das variáveis estáticas.

Regarding the dynamic variables, percent variations are presented in Table 1 . In population density, the low risk class decreased from 2010 to 2100 , going from 65.91 to $51.95 \%$, and the extreme risk went from 13.58 to $26.73 \%$ of the state. To the fuel load moisture content, in the best-case scenario, the high, very high and extreme risk classes totaled an area of 5,063,504.88 ha (53.11\%) in $2010-2020$ and in the period $2090-2100$, there was a reduction to $4,806,279.96$ ha $(50.42 \%)$. In the worst-case scenario, the trend remained, but the most representative risk was the moderate one, with 33.32\% in the period from 2010 to 2020, showing a slight decrease in 2100 (30.12\% of the total). The extreme risk class represented $19.79 \%$ in $2010-2020$, with an increase of $2.53 \%$ in 2100 . In the evaluation of the FMA, for the best-case scenario in the decade of $2010-$ 2020, the low and moderate risk classes represented $62.94 \%$ and $37.06 \%$, respectively, and the other classes were non-existent, whereas, in 2100 , the high, very high and extreme risk classes corresponded to $64.36 \%$ of the area. In the worst-case scenario, the low risk class showed a drop of $28.48 \%$ in relation to the best-case scenario 
in the decade from 2010 to 2020, and the most representative class was the moderate risk with $64.02 \%$ of the state. At the end of the century, the high, very high and extreme risk classes increased $5.8 \%$.

Table 1. Variation of the dynamic variables in 2010-2020 and 2090-2100 relative to the risk of forest fires.

Tabela 1. Variação das variáveis dinâmicas em 2010-2020 e 2090-2100 em relação ao risco de incêndios florestais.

\begin{tabular}{llll}
\hline Static Variables & Risk Class & $\mathbf{2 0 1 0 - 2 0 2 0}(\mathbf{\%})$ & $\mathbf{2 0 9 0 - 2 1 0 0}(\mathbf{\%})$ \\
\hline & Low & 65.9 & 52.0 \\
& Moderate & 13.7 & 10.1 \\
Population Density & High & 4.4 & 7.3 \\
& Very High & 2.5 & 4.0 \\
& Extreme & 13.6 & 26.7 \\
\hline \multirow{4}{*}{ Fuel Load Moisture } & Low & 8.9 & 15.3 \\
Content (Best-case & Moderate & 38.0 & 34.3 \\
Scenario) & High & 20.3 & 16.6 \\
& Very High & 12.6 & 11.4 \\
& Extreme & 20.3 & 22.4 \\
Fuel Load Moisture & Low & 8.6 & 14.2 \\
Content (Worst-case & Moderate & 33.3 & 30.1 \\
Scenario) & High & 25.0 & 21.2 \\
& Very High & 13.4 & 12.2 \\
& Extreme & 19.8 & 22.3 \\
\hline \multirow{4}{*}{ Monte Alegre Formula } & Moderate & 62.9 & 19.5 \\
(Best-case Scenario) & High & 0.0 & 16.2 \\
& Very High & 0.0 & 19.4 \\
& Extreme & 0.0 & 34.7 \\
\hline \multirow{2}{*}{ Monte Alegre } & Low & 34.5 & 10.3 \\
Formula (Worst-case & Moderate & 64.0 & 3.5 \\
& High & 1.5 & 26.3 \\
& Very High & 0.0 & 28.5 \\
& Extreme & 0.0 & 34.6 \\
\hline
\end{tabular}

The Forest Fire Risk Zone Mapping (ZRIF) was generated to the state from preliminary maps, resulting in nine maps for each scenario, which present the beginning and end of the century (Figure 2). In the best-case scenario, the risk in the first decade (2010 - 2020) is concentrated on the moderate and high classes, with 44.59 and 25.07 respectively, of which the greatest part of the area is located in the mountainous region. In relation to extreme risk (11.19 of the total), the largest part of the area is located in the west of Santa Catarina (73.82). This behavior persists until the decade $2070-2080$, when the high and very-high risk classes become the most representative, with 26.10 and 22.61 , respectively. In 2100 , the percentage corresponding to the low risk class was 10.04. Of these, 40 of the area is located in the mountainous region. The other risks had similar proportions: the moderate risk obtained 20.08, the high risk 24.06, the very high risk 23.15, and the extreme risk 22.67. The latter, as in the first decade, had the greatest part of its area located in the west of Santa Catarina. In the worstcase scenario, the decade of 2010 - 2020 presented a distribution of 15.10 for the low risk class, 26.81 for the moderate risk class, 27.51 for the high risk class, 18.15 for the very high risk class, and 12.44 for the extreme risk class, following the same trend of the best-case scenario, in which the most representative risks were also moderate and high, and the greatest part of the area was located in the mountainous region with 30.51 and 26.63 , respectively. Over the decades, the risks low and moderate were decreasing, scenery that changes in the period 2060 - 2070 when the high and very high risks come to be the most representative ones. In the last decade, the state of Santa Catarina did not present more area in the moderate and very high risk classes, transferring part of the area for the high risk class (50.01). Analyzing the extreme risk class (23.27), the state obtained an increase of 87 from 2010 to 2100 , equivalent to $1,026,659.60$ ha. 

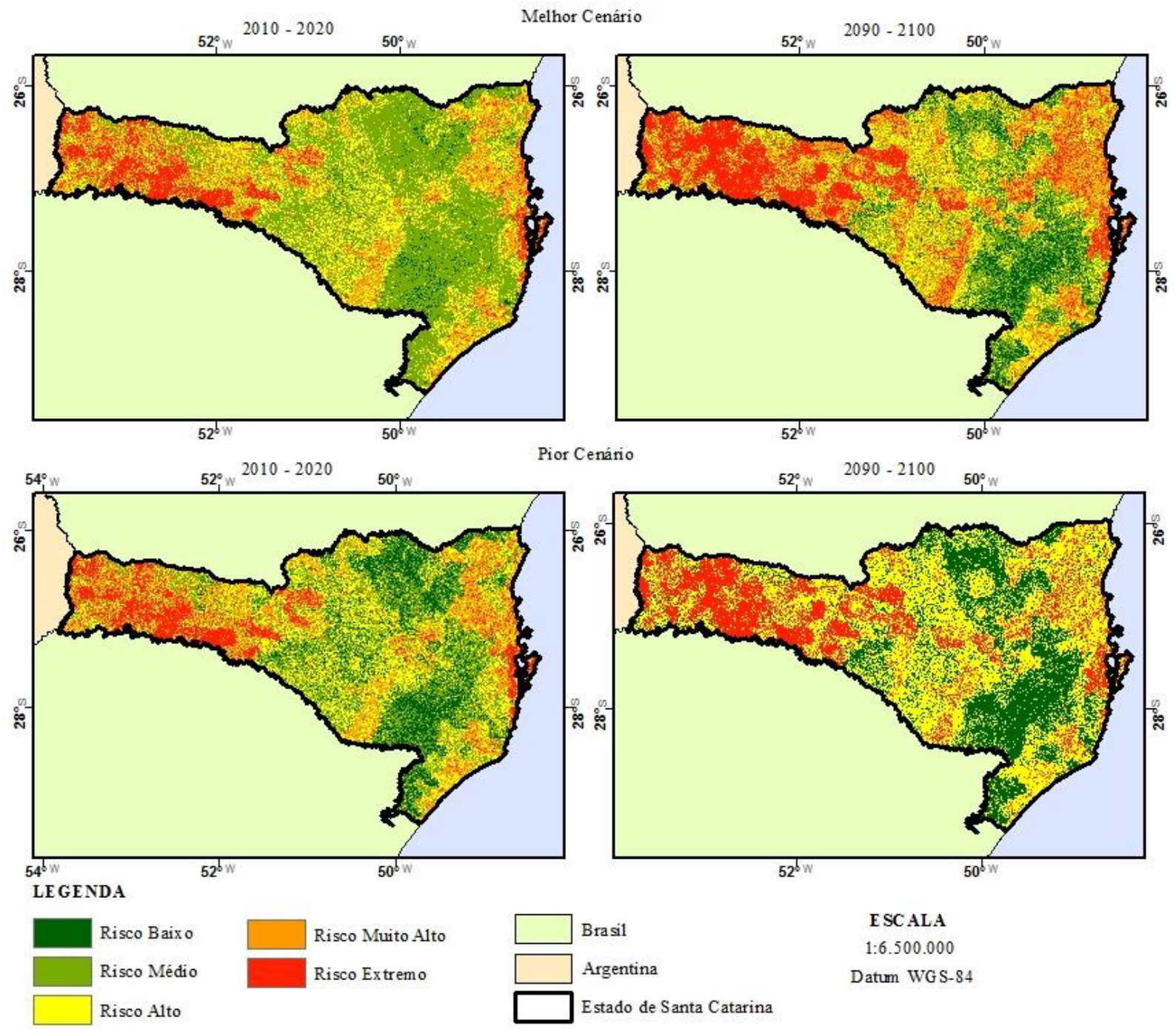

Figure 2. Forest Fire Risk Zone Mapping for the period 2010 - 2020 and 2090 - 2100 for the best-case and worst-case scenarios.

Figura 2. Mapas do Zoneamento de Risco de Incêndios Florestais para o período de 2010 - 2020 e 2090 - 2100 para o melhor e pior cenários.

\section{DISCUSSION}

The static variables influenced the composition of the ZRIF over time in a constant manner. The vegetation cover mainly affected the west of Santa Catarina and the mountainous region, areas that concentrated the largest part of the extreme risk (68.46) given by the amount of pasture and forest cultivation in the region. Pine plantations deposit a large quantity of needles into the soil and have physical and chemical properties susceptible to the action of fire, as well as the accumulation of fuel load in eucalyptus plantations (WHITE; RIBEIRO; SOUZA, 2014). The orientation of the slopes had a low influence on the zoning, since a large part of the state is classified as low risk, same result observed by White, White and Ribeiro (2016) in Inhambupe, BA, Brazil. Slope followed the same trend; 49.30 of the state has a slope up to 15. In relation to the altitude, there is a high risk in the region near the coast and the west of the state due to lower altitudes that facilitate the spread of forest fires. The road system makes certain forest areas more accessible to human activities than others, highlighting a risk that must be considered in a fire-occurrence modeling (GANTEAUME et al., 2012).

The dynamic variables were those that provided differences between the decades and between the analyzed scenarios. We noticed a trend towards an increase in population density in locations near the coast and in the west of the state, regions that require more prevention actions, since the human presence increases the chances of deliberate and accidental fires, mainly in recreational areas that had forest conversion to pasture

FLORESTA, Curitiba, PR, v. 47, n.4, p. 427 - 436, out/dez. 2017.

Lima Ho, T. et al.

ISSN eletrônico 1982-4688

DOI: $10.5380 /$ rf.v47i4.50877 
(HOYO; ISABEL; VEGA, 2011). Syphard et al. (2007) diagnosed that the population density in California (USA ) was one of the factors that increased the occurrence of fires in the region. This variable is, thus, an important element that will influence the increased risk of fire at the end of the century.

Climatic factors were represented by the variables: fuel load moisture content and fire danger index (FMA). In relation to the fuel load moisture content, there was little interference in the increase of fire risk from 2010 to 2100, and between the scenarios analyzed, which showed, for both analyses, the concentration of the extreme risk in the west due to the lower levels of relative humidity of the air and high temperatures, weather conditions that reduce the moisture content from fuels, making it a favorable environment for the ignition (LIU et al., 2012). The Monte Alegre Formula is widely used in several municipalities in Brazil to predict the danger of forest fires, which have had their risk boosted with the increase of the temperature of the Earth. In this study, it was the determining factor in the zoning of the state at the beginning and at the end of the century.

The integration of the static and dynamic variables showed that, over time, there will be an increase in the risk of forest fires in Santa Catarina for both case scenarios. In comparison with the state of Paraná, this study found the same behavior. In the best-case scenario, the most representative classes at the beginning of the century (2010 - 2020) were the moderate and high risks, and, at the end of the century $(2090-2100)$, the high and very high risks. In the worst-case scenario, the high-risk class was the most representative one in the first decade, but at a lower intensity compared to that of the state of Paraná. In the last decade, the very high risk class was the most representative class, with 51.74 to the state of Paraná, and 50.01 to the state of Santa Catarina (BATISTA et al., 2014). Instruments such as Forest Fire Risk Zone Mapping and risk maps are essential to plan, to prevent and to fight forest fires, thereby minimizing the negative effects of the fire.

\section{CONCLUSIONS}

The analyses allowed us to conclude that:

- The state will have their risk of fire increased until the end of the century, noting the hypothesis that there will be more chances of forest fires to occur with the increase in the temperature of the Earth.

- There was little variation when comparing the results of the best-case and the worst-case scenarios. Thus, it is recommended to use the extreme values of each scenario, and not their means for future studies.

- The dynamic variables (population density, fuel load moisture content, fire danger index) showed an increase in the highest classes of fire risk over time and impacted the extreme class of the forest fire risk zone mapping directly.

- The integration model was satisfactory, generating data compatible with the hypothesis at issue, due to the evolution of the highest risks over the decades.

\section{ACKNOWLEDGEMENTS}

To the Agency for the Financing of Studies and Projects (FINEP) for making this study possible.

To the professionals of IAPAR and SIMEPAR: Marciel Lohmann, Paulo Henrique Caramori, Flavio Deppe and Cesar Augustus Assis Beneti for all the support given.

To Prof. Dr. Jorim Sousa das Virgens Filho, State University of Ponta Grossa, (Universidade Estadual de Ponta Grossa (UEPG)) for having assisted in the simulations of PGECLIMA_R.

\section{REFERENCES}

BATISTA, A. C.; TETTO, A. F.; DEPPE, F.; GRODZKI, L.; GRASSI, J. T. Análise dos impactos das mudanças climáticas sobre o risco de incêndios florestais no estado do Paraná. Sci. For., Piracicaba, v. 42, n. 104, p. 491 501, 2014.

BRANDÃO, C. B.; MIRANDA, A. A. C. Relações entre elementos climáticos e geográficos nas ocorrências de incêndio florestal no Parque Estadual da Pedra Branca - RJ. Revista Brasileira de Climatologia, Curitiba, v. 10, n. 1, p. 171-184, 2012.

EMPRESA DE PESQUISA AGROPECUÁRIA E EXTENSÃO RURAL DE SANTA CATARINA (EPAGRI); INSTITUTO BRASILEIRO DE GEOGRAFIA E ESTATÍSTICA (IBGE). Mapoteca topográfica digital de Santa Catarina, 2004. Available at: 〈http://ciram.epagri.sc.gov.br/mapoteca/pre_download_mapa_shp.jsp〉. . Accessed on: 11 Jan. 2016. 
EUGÊNIO, F. C.; SANTOS, A. R.; FIEDLER, N. C.; RIBEIRO, G. A.; SILVA, A. G.; SANTOS, Á. B.; PANETO, G. G.; SCHETTINO, V. A. Applying GIS to develop a model for forest fire risk: a case study in Espírito Santo, Brazil. Journal of Environmental Management, v. 173, p. 65-71, 2016.

GANTEAUME, A.; CAMIA, A.; JAPPIOT, M.; SAN-MIGUEL-AYANZ, J., LONG-FOURNEL, M., LAMPIN, C. A review of the main driving factors of forest fire ignition over Europe. Environmental management, New York, v. 51, n. 3, p. 651-662, 2012.

GUILLERMO JULIO, A. Método de determinación de prioridades de protección. Santiago: Universidad de Chile, Facultad de Ciencias Agrarias y Forestales, 1992. 27 p. (Manual n. 10).

HIGUERA, P. E.; BRUBAKER, L. B.; ANDERSON, P. M.; HU, F. S.; BROWN, T. A. Vegetation mediated the impacts of postglacial climate change on fire regimes in the south-central Brooks Range, Alaska. Ecological Monographs, Washington, v. 79, n. 2, p. 201-219, 2009.

HOYO, L. V.; ISABEL, M. P. M.; VEGA, F. J. M. Logistic regression models for human-caused wildfire risk estimation: analysing the effect of the spatial accuracy in fire occurrence data. European Journal of Forest Research, v. 130, n. 6, p. 983-996, 2011.

INSTITUTO BRASILEIRO DE GEOGRAFIA E ESTATÍSTICA (IBGE). Censo 2010. Available at: <http://www.censo2010.ibge.gov.br/>. Accessed on: 11 Mar. 2016. p. $1-54,2014$

Ministério do Planejamento, Orçamento e Gestão. Rio de Janeiro. Anuário estatístico do Brasil, v. 74,

INSTITUTO NACIONAL DE PESQUISAS ESPACIAIS (INPE). TOPODATA: Banco de dados geomorfométricos do Brasil, 2008. Available at: <www.dsr.inpe.br/topodata/>. Accessed on: 11 Mar. 2016.

INTERGOVERNMENTAL PANEL ON CLIMATE CHANGE (IPCC). Climate Change 2013: the physical science basis. New York: Cambridge University Press, 2013. 1535 p.

KEANE, R. E.; DRURY, S. A.; KARAU, E. C.; HESSBURG, P. F.; REYNOLDS, K. M. A method for mapping fire hazard and risk across multiple scales and its application in fire management. Ecological Modelling, v. 221, n. 1, p. 2-18, 2010.

LIU, Z.; YANG, J.; CHANG, Y.; WEISBERG, P. J.; HE, H. S. Spatial patterns and drivers of fire occurrence and its future trend under climate change in the boreal forest of Northeast China. Global Change Biology, v. 18, p. 2041-2056, 2012.

MACHADO, N. G.; SILVA, F. C. P.; BIUDES, M. S. Efeito das condições meteorológicas sobre o risco de incêndio e o número de queimadas urbanas e focos de calor em Cuiabá - MT, Brasil. Ciência e Natura, Santa Maria, v. 36, n. 3, p. 459-469, 2014.

MINISTÉRIO DO MEIO AMBIENTE (MMA). Dados geográficos. Base cartográfica. Transporte, 2008. Available at: < http://mapas.mma.gov.br/i3geo/datadownload.htm>. Accessed on: 11 Jan. 2016.

NUNES, J. A. S.; FIER, I. S. N.; SOARES, R. V.; BATISTA, A. C. Desempenho da Fórmula de Monte Alegre (FMA) e da Fórmula de Monte Alegre Alterada (FMA+) no Distrito Florestal de Monte Alegre. Floresta, Curitiba, v. 40, n. 2, p. 319-326, 2010.

POURTAGHI, Z. S.; POURGHASEMI, H. R.; ROSSI, M. Forest fire susceptibility mapping in the Minudasht forests, Golestan province, Iran. Environmental Earth Sciences, v. 73, n. 4, p. 1515-1533, 2015.

SALAS, J.; CHUVIECO, E. Geographic information systems for wildland fire risk mapping. Wildfire, Washington, v. 3, n. 2, p. 7-13, 1994.

SIMARD, A. J. The moisture content of forest fuels - I. Ottawa, Ontario: Forest Fire Research Institute, 1968. 47 p. (Inf. Report FF - X - 14).

SYPHARD, A. D.; RADELOFF, V. C.; KEELEY, J. E.; HAWBAKER, T. J.; CLAYTON, M. K.; STEWART, S. I.; HAMMER, R. B. Human influence on California fire regimes. Ecological applications, v. 17, n. 5, p. 1388-1402, 2007.

VIRGENS FILHO, J. S.; LEITE, M. L.; FRANCO, J. R.; KORELO, M. Modelo computacional estocástico para simulação de séries climáticas diárias de umidade relativa do ar, baseado na parametrização dinâmica das

FLORESTA, Curitiba, PR, v. 47, n.4, p. 427 - 436, out/dez. 2017.

Lima Ho, T. et al.

ISSN eletrônico 1982-4688

DOI: $10.5380 /$ rf.v47i4.50877 
distribuições de probabilidade decorrente da retroalimentação de dados. Revista Brasileira de Climatologia, Curitiba, v. 5, p. 133-151, 2009.

VON SPERLING, M. Princípios do tratamento biológico de águas residuárias: introdução à qualidade das águas e ao tratamento de esgotos. 3. ed. Departamento de Engenharia Sanitária e Ambiental: UFMG, 2005. 452 p.

WHITE, B. L. A.; RIBEIRO, G. T.; SOUZA, R. M. Caracterização do material combustível e simulação do comportamento do fogo em eucaliptais no litoral norte da Bahia, Brasil. Revista Floresta, Curitiba, v. 44, n. 1, p. 33-42, 2014.

WHITE, L. A. S.; WHITE, B. L. A.; RIBEIRO, G. T. Modelagem espacial de risco de incêndio florestal para o município de Inhambupe, Bahia, Brasil. Pesq. flor. bras., Colombo, v. 36, n. 85, p. 41-49, 2016. 